\title{
Applying Intermediate Microeconomics to Terrorism
}

\author{
Charles H. Anderton \\ and \\ John R. Carter
}

August 2004

\section{COLLEGE OF THE HOLY CROSS, DEPARTMENT OF ECONOMICS \\ FACULTY RESEARCH SERIES, WORKING PAPER NO. 04-12*}

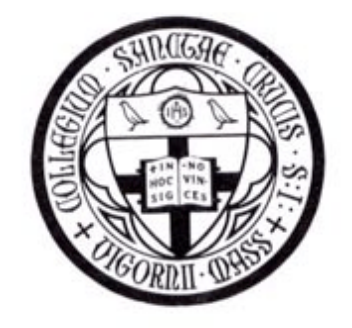

Department of Economics

College of the Holy Cross

Box 45A

Worcester, Massachusetts 01610

(508) 793-3362 (phone)

(508) 793-3710 (fax)

http://www.holycross.edu/departments/economics/website

*All papers in the Holy Cross Working Paper Series should be considered draft versions subject to future revision. Comments and suggestions are welcome. 


\title{
Applying Intermediate Microeconomics to Terrorism
}

\author{
By \\ Charles H. Anderton ${ }^{\dagger}$ \\ College of the Holy Cross \\ and \\ John R. Carter ${ }^{\dagger+}$ \\ College of the Holy Cross
}

August 2004

\begin{abstract}
The authors show how microeconomic concepts and principles are applicable to the study of terrorism. The utility maximization model provides insights into both terrorist resource allocation choices and government counterterrorism efforts, while basic game theory helps characterize the strategic interdependencies among terrorists and governments.
\end{abstract}

JEL Classification Codes: A12, A22, C70, D11, D74, H41, H56

Keywords: terrorism; rational choice model; income and substitution effects; Slutsky equation; game theory; prisoners' dilemma; chicken; public goods

${ }^{\dagger}$ Charles H. Anderton, Department of Economics, Box 85A, College of the Holy Cross, Worcester, MA 01610-2395, 508-793-3441 (phone), 508-793-3710 (fax), canderto@holycross.edu

${ }^{\dagger \dagger}$ John R. Carter, Department of Economics, Box 147A, College of the Holy Cross, Worcester, MA 01610-2395, 508-793-2676 (phone), 508-793-3710 (fax), jcarter@holycross.edu 


\section{Applying Intermediate Microeconomics to Terrorism}

Students expect a microeconomics course to explore the behavior of consumers, producers, and governments in the marketplace. What they find surprising is how far and wide the economic theory of choice casts its net in exploring human behavior. In this article we apply the utility maximization model to terrorists' resource allocation and targeting behavior and to governments' counterterrorism efforts. We also discuss selected game theoretic aspects of terrorism and counterterrorism. In the conclusion we highlight the benefits of teaching the economics of terrorism in intermediate microeconomics.

\section{SOME BACKGROUND ON TERRORISM}

\section{Definition}

There is considerable debate among scholars over how terrorism is to be distinguished from other forms of violence, such as armed robbery or nation-state warfare (Hoffman 1998, ch. 1). For the purposes of this paper, we adopt Sandler and Hartley's $(1995,308)$ definition of terrorism as "the premeditated use, or threat of use, of extra-normal violence or brutality to gain a political objective through intimidation or fear." By this definition, terrorism is fundamentally political in the sense that terrorists desire to "change the system," something that is not a priority for ordinary criminals (Hoffman 1998, 42). Unlike nation-states, terrorists operate outside the usual rules of warfare pertaining to civilians, diplomats, prisoners, and neutral parties. Hence, terrorist acts involve extra-normal violence such as indiscriminate attacks against civilians, hostage-taking of diplomats, and execution of kidnapped military officers (Hoffman 1998, 3435). Finally, note that terrorist activities are rich in externalities because they are designed to have psychological effects that extend beyond the immediate victims. 


\section{Historical Data}

Selected annual series involving international and/or domestic terrorism worldwide are shown in Figures 1-3; underlying data are available Table A of the appendix. The data source is RAND/Memorial Institute for the Prevention of Terrorism (RAND-MIPT) (www.rand.org/psj/rand-mipt.html). According to RAND-MIPT, “international terrorism includes incidents in which the perpetrators go abroad to strike their targets, select domestic targets associated with a foreign state, or create an international incident by attacking airline passengers or equipment." Examples of international terrorism are al Qaeda's attacks against U.S. embassies in Kenya and Tanzania in 1998 and the World Trade Center and Pentagon in 2001. Domestic terrorism is defined by RAND-MIPT as "incidents perpetrated by local nationals against a purely domestic target," such as the fire set by the Earth Liberation Front in 2001 that destroyed a building at the University of Washington's Center for Urban Horticulture. RAND-MIPT has compiled annual data for international terrorism from 1968 and for domestic terrorism from $1998 .^{1}$

Figure 1 shows the time paths for international terrorist incidents and for domestic terrorist incidents (divided by 10). Three summary observations follow. First, contrary to popular impression, no upward (linear) trend is evident in the international incidents series for the full sample period $1968-2003 .^{2}$ Despite the notoriety of the $9 / 11$ attacks in the United States, the number of international incidents is below the mean in five of the last six years in Figure 1. Second, domestic terrorism incidents around the world are much more numerous than international incidents, at least for the limited period of 1998-2003. Third, there is a strong positive correlation between the number of international and domestic incidents, again for the limited period for which data are available. Given students' interest in international terrorism 
and the limited availability of domestic terrorism data, the remainder of the paper focuses on international terrorism.

\section{Figure 1 here}

Figure 2 shifts attention to casualties (deaths plus injured) and casualties per incident caused by international terrorism worldwide. In contrast to Figure 1, upward trends are evident in both series, suggesting that international terrorism is increasing in severity. ${ }^{3}$ Particularly noticeable is the higher casualty rates since the end of the Cold War. Enders and Sandler (2000) studied the increased deadliness of terrorism using time-series techniques and concluded that terrorist incidents since 1991 (through 1996 in their data) were 17 percentage points more likely to result in casualties relative to incidents in the preceding two decades. They and other analysts attribute the increased deadliness to the growth in religiously-motivated acts of terrorism (Enders and Sandler 2000, 329-330; Hoffman 1998, ch. 4; Juergensmeyer 2000; for criticisms of “religion and violence" perspectives on terrorism, see Cavanaugh 2004).

\section{Figure 2 here}

Figure 3 summarizes the frequency of international terrorist strikes against political and civilian targets. While recognizing that all terrorist incidents by definition are fundamentally political, we classify terrorist attacks against governments, diplomats, or the military as political. Civilian targets involve strikes against airlines and airports, businesses, journalists, nongovernmental organizations, private citizens and property, religious organizations, transportation assets, and utilities. Figure 3 shows that international terrorists in the aggregate chose civilian and political targets with roughly equal frequency during the Cold War years. Since 1990, however, a greater frequency of civilian relative to political targets has emerged.

\section{Figure 3 here}




\section{RATIONAL CHOICE MODEL OF TERRORISM}

The rational choice model can be applied to terrorism by assuming that individuals and organizations have preferences over terrorist as well as ordinary activities. For most purposes, it is sufficient to carry out the analysis in terms of two commodities, terrorism $T$ and composite good $C$, where the latter is defined as real expenditures on all goods other than $T{ }^{4}$ Standard indifference curves can be used to show terrorists' preferences over $T$ and $C$, with $T$ on the horizontal axis. A relatively high degree of curvature of the indifference curves would imply a relatively low degree of substitutability between $T$ and $C$. If terrorists are particularly strident in their willingness to sacrifice some $C$ to achieve an increment to $T$, they would have steep indifference curves in $T$ - $C$ space. Non-terrorists receive no utility or even disutility from $T$, so their indifferences curves would be flat or upward sloping.

For some applications, terrorist preferences can be assumed over alternative targets, for example, political and civilian targets. The lesser the curvature of the indifference curves, the more willing terrorists are to substitute among targets. Regarding al Qaeda's targeting philosophy, Osama bin Laden has been quoted: "We do not differentiate between those dressed in military uniforms and civilians. They're all targets." suggests that al Qaeda's indifference curves over military and civilian targets may be virtually linear (perfect substitutes). Horizontal or vertical indifference curves would apply to terrorists who are strictly motivated to strike one target class but not the other.

For general applications, we assume that terrorists have income $I$, which can be allocated over $T$ and $C$ according to the budget constraint $I=P_{T} T+P_{C} C$, where $P_{T}$ is the price (cost) of carrying out terrorist activities and $P_{C}$ is the price of the composite good. For applications pertaining to targeting, we assume that an exogenous amount of resources $R_{T}$ are allocated to 
terrorist activities. The budget constraint then becomes $R_{T}=P_{1} T_{1}+P_{2} T_{2}$, where $T_{1}$ and $T_{2}$ are targets (e.g., political and civilian) and $P_{1}$ and $P_{2}$ are the prices of carrying out the respective missions. $^{6}$

Assuming an interior solution, the utility maximizing choice of $T$ and $C$ occurs where the absolute value of the marginal rate of substitution of $T$ for $C$ is equal to the relative price of terrorism $P_{T} / P_{C}$. Geometrically, this is shown by the tangency of the terrorist organization's indifference curve to its budget constraint. By altering the key parameters of the rational choice model (i.e., income, prices, preferences), various aspects of terrorism behavior and counterterrorism policy can be explored. ${ }^{7}$

\section{APPLICATIONS OF THE RATIONAL CHOICE MODEL}

\section{Terrorist Access to Resources: Income-Consumption and Engel Curves}

Terrorist groups are dependent upon financial resources to carry out terrorist activities, so they obviously strive to maintain or increase their income. In Figure 4(a), assume the terrorist group has carried out a spectacular hijacking (e.g., 9/11) or hostage incident (e.g., 1972 Munich

Olympics), which generates publicity and new financial support for the terrorist group among its sympathizers. This shifts out the group's budget constraint from $a a$ to $b b$, which allows the group to acquire more terrorism and other goods. The income-consumption curve in Figure 4(a) implies an Engel curve for terrorism in Figure 4(b), which can be used to explore the income elasticity of terrorism. If the composite good, consisting largely of consumer goods like food, clothing, and housing, is viewed by terrorists as a necessity, then $C$ would be income-inelastic. Because weighted income elasticities sum to one, this would imply that terrorism is incomeelastic, as reflected in the relatively flat slope of the Engel curve in Figure 4(b).

\section{Figure 4 here}


While terrorists attempt to increase their resources, governments, as part of counterterrorism policy, attempt to reduce resources available to terrorists by freezing or seizing financial assets and disrupting flows of funds associated with terrorist activities. For example, the USA Patriot Act of 2001 expanded the power of Federal authorities to restrain money laundering via new regulations, criminal sanctions, and forfeiture rules. In Figure 4(a), assume counterterrorism income policies reduce the budget constraint of the terrorist group from $b b$ to $a a$. If terrorism is income-elastic, counterterrorism income policies could be particularly effective in reducing terrorism. Moreover, if terrorist activities generate publicity and enhance future terrorist fund-raising, counterterrorism income policies today could reduce future terrorism.

\section{Terrorist Response to Price Changes: The Price-Consumption Curve}

In addition to income policies, governments attempt to thwart terrorism with price policies. For example, greater defense of potential targets, attacks against terrorist training centers, capture of terrorist leaders, and infiltration of terrorist groups increase the price of terrorism $P_{T}$. Raising the opportunity cost of terrorism by making terrorist activities more expensive is classified by some scholars as deterrence policy. In contrast to deterrence policy, Frey and Luechinger (2003) investigate the potential for "benevolence policy" to reduce terrorism. A benevolence policy raises the opportunity cost of terrorist activities, not by increasing the price of terrorism, but by reducing the price of the composite good.

Figure 5 compares and contrasts deterrence and benevolence price policies to reduce terrorism. Assume the initial budget constraint available to the terrorists is $a a$. According to Figure 5, terrorists consume $T_{l}$ in terrorist activity and $C_{l}$ of other goods. A deterrence policy increases the price of terrorism $P_{T}$ by raising the expected costs of terrorist activity, causing the 
budget constraint to rotate in along the $T$ axis to budget line $a b$. The increased opportunity cost of terrorism is reflected in the steeper slope of the budget line. Consistent with the law of demand, terrorist activity is reduced to some lower level $T_{2}$.

A benevolence policy also raises the opportunity cost of terrorism, but it does so by increasing terrorist access to other goods by lowering $P_{C}$. This is shown in Figure 5 by budget line $c a$. Again, the steeper budget line reflects a higher opportunity cost of terrorism. Under the price-reducing benevolence policy, terrorists choose a reduced level of terrorism, which for convenience is drawn equal to $T_{2}$, the same level as under deterrence.

\section{Figure 5 here}

In Figure 5, the decrease in $P_{C}$ reduces terrorism from $T_{1}$ to $T_{2}$. However, it is also logically possible for a decrease in $P_{C}$ to have the opposite effect and instead increase terrorism. This can easily be seen by redrawing the final indifference curve such that the optimum on budget line $c a$ falls to the right of terrorist level $T_{l}$. The two possibilities are distinguished by the slopes of their respective price-consumption curves, which in turn are linked to different values of the own price elasticity of the composite good $\varepsilon_{C C}$. In the case depicted in Figure 5, a decrease in $P_{C}$ generates a new optimum along a negatively-sloped price-consumption curve and hence a decreased level of terrorism. This occurs if and only if the composite good is price elastic. In the alternative case, a decrease in $P_{C}$ results in a new optimum along a positivelysloped price-consumption curve and thus an increased level of terrorism. This occurs if and only if the composite good is price inelastic. ${ }^{8}$

\section{Terrorist Substitution Possibilities and the Slutsky Equation}

An important general issue raised by terrorism-thwarting price policies is the potential for terrorists to substitute into other activities. For example, the question raised by consideration of 
benevolence policy is whether terrorism will increase or decrease in response to a lowering of $P_{C}$. A similar issue arises when considering whether greater protection of political targets will increase or decrease terrorist attacks against civilians. The scope of terrorist substitution possibilities is extensive. For example, terrorists can substitute between terrorism and ordinary goods, across target classes, among weapons technologies, across countries, and over time (Sandler 2003, 794-796). The rational choice model cannot by itself provide unambiguous answers to the direction and magnitude of terrorist substitution behavior. It can, however, provide valuable guidance.

The guidance comes from the rational choice model's well-known Slutsky equation. In terms of elasticities, the equation can be formally stated for the case of terrorist substitution into activity $i$ given a change in the price of activity $j, \varepsilon_{i j}$, as:

$$
\varepsilon_{i j}=\sigma_{i j}-\alpha_{j} \eta_{i}
$$

where $\sigma_{i j}$ is the compensated price elasticity of activity $i$ with respect to a change in the price of activity $j, \alpha_{j}$ is the budget share of activity $j$, and $\eta_{i}$ is the income elasticity of activity $i$.

When $i=j$ in equation (1), standard income and substitution effects can be considered, as is done in virtually all intermediate microeconomics texts. For example, if $i=j=T$, then one can evaluate the income and substitution effects of a higher price of terrorism on the quantity of terrorism.

When $i \neq j$, the Slutsky equation can be used to study terrorist substitution across activities. For example, the Slutsky equation can be applied to the question above of whether a benevolence policy lowering $P_{C}$ would increase or decrease terrorism. Let $i$ be terrorism and $j$ be the composite good encompassing food, clothing, shelter, etc. The Slutsky equation decomposes the elasticity of terrorism with respect to a change in the price of the composite good into 
substitution and income effects. Recall from rational choice theory that not all goods can be net complements. Hence, in the case of two goods only, $T$ and $C$ must be net substitutes. This means that the substitution effect is necessarily positive (with lower $P_{C}$ implying lower $T$ ). The substitutability between terrorism and other goods is presumably limited, however, implying that the substitution effect is small. For the income effect, the minus sign on the Slutsky equation's second term shows that a decrease in $P_{C}$ causes an increase in real income, where the increase is larger the greater is the composite good's budget share. Due to the minus sign, the sign of the income effect will be opposite that of the income elasticity of terrorism. Both intuition and evidence (see Krueger and Malečková 2003) indicate that terrorism is a normal good such that the income elasticity is positive. This, together with a presumably large budget share for the composite good, suggests that the income effect will be negative (with lower $P_{C}$ implying higher T) and large, possibly dominating a small positive substitution effect. Hence, there is good reason to believe that the sign of $\varepsilon_{T C}$ is in fact negative, meaning that a decrease in the price of the composite good would actually increase terrorism.

The Slutsky equation can be applied to other terrorist substitution possibilities. Consider Table 1, which shows the decline in hijackings in absolute terms and as a percent of international terrorism incidents following the placement of metal detectors in airports around the world in 1973. Table 1 seems consistent with rational choice theory whereby an increase in the relative price of hijackings was associated with a decline in the absolute and relative number of hijackings. What about terrorist substitution possibilities into other modes of attack following the new constraint against hijackings? Enders and Sandler $(1993,1995)$ employ time-series analysis to ascertain the effects of policies directed at inhibiting attacks on particular targets. Among their stronger results, they show that the placement of metal detectors had the unintended 
consequence of significantly increasing hostage incidents and assassinations. In terms of the Slutsky equation, this suggests large positive substitution effects across targets and at most only partially offsetting income effects associated with the increased price of hijackings. ${ }^{9}$

\section{Table 1 here}

\section{Preference Policies}

Although economists often take preferences as given and then focus on the effects of income and price changes on key variables, counterterrorist efforts to modify terrorist preferences are worth considering. ${ }^{10}$ Presumably the goal of counterterrorist preference policies is to make terrorist preference maps horizontal in $T$ - $C$ space, such that terrorists receive no utility from terrorist activities. In the rational choice model, an important exogenous variable that might alter preferences is advertising. Since terrorist preferences appear to be formed within a complex web of cultural, historical, political, and idiosyncratic variables, it may be overly optimistic to believe that counterterrorist "advertising campaigns" by governments could flatten terrorist preferences. Nevertheless, there may be some important effects of advertising at the margin.

Consider, for example, the Iraqi prisoner abuse scandal of 2004. It is likely that the degrading images of Iraqi prisoners hardened the preferences of terrorists against the United States. It may have also created terrorist preferences among some individuals who previously had flat indifference curves in $T-C$ space. Hence, the prisoner abuse scandal can be seen as a form of "negative advertising" that may have reshaped terrorist preferences toward more terrorism. The obvious implication is that counterterrorist policy should reduce the risk of catalytic events such as the prisoner abuse scandal or the accidental bombing of religious sites. 
"Positive advertising" campaigns can and do take many forms. For example, governments are aware of regions of the world where terrorists reside or where the potential for terrorist recruiting is relatively high. Some of these regions face a relatively high risk of natural disasters (earthquakes, hurricanes, etc.). Extra-normal publicity of natural disaster relief by the United States in these regions might affect terrorist preference formation at the margin.

Of course, terrorists also carry out advertising campaigns. Terrorist recruiters portray the evils of the enemy and attempt to convince people about the rightness of their cause. Hence, governments and terrorist organizations can be viewed as engaged in an "advertising war" for the hearts and minds of people in strategic locales such as Iraq, Afghanistan, and Saudi Arabia. In this advertising game, each side tries to gain "market share" by affecting what people know, or think they know, about themselves, governments, and terrorists. The advertising game is just one of many dimensions of game theoretic interaction between terrorists and governments.

\section{GAME THEORETIC PERSPECTIVES OF TERRORISM}

The strategic interdependence between terrorists and governments, and between governments themselves as they attempt to thwart terrorism, implies that game theory can be a useful supplement to the rational choice model in the analysis of terrorism. In this section we selectively apply basic game theory to terrorism. The applications that follow allow students to see a variety of concepts, principles, and games from intermediate microeconomics texts such as Pareto efficiency, public goods, externalities, backward induction (or rollback), and the prisoners' dilemma.

\section{Government-Terrorist Hostage Game}

Lapan and Sandler (1988) present an extensive form game showing the time pattern of choices between a terrorist organization considering a hostage mission and a government 
deciding whether to negotiate for the hostages' release. The game tree for the hostage event is shown in Figure 6. The government chooses deterrence expenditure, $D$, which we treat as a sunk cost. The game tree begins with the terrorists deciding whether or not to attack. If the terrorists do not attack, the status quo obtains with a payoff of 0 to each player. If the terrorists attack but fail to capture the hostages, they endure payoff $-L<0$. The government also bears a loss from a failed terrorist mission (e.g., loss of life of security forces, expenditure of resources), which is equal to $-A<0$ in Figure 6. If the terrorists attack and succeed in capturing the hostages, the government must decide whether to negotiate with the terrorists. If the government negotiates, the terrorist organization obtains a payoff of $M>0$ and the government suffers a loss of $-B<-A$. If the government does not negotiate, the terrorist organization receives payoff $N<M$, where $N$ may be positive or negative. When the government does not negotiate, it suffers a loss $-C<-B$. The probability of terrorist logistical failure is $\theta$ and the probability that the government negotiates given terrorist logistical success is $p$.

Figure 6 here

From the game tree in Figure 6, the expected payoff $Z$ to the terrorists from initiating a hostage mission is (Lapan and Sandler 1988, 17):

$$
Z=-\theta L+(1-\theta)[p M+(1-p) N]
$$

If $Z>0$, the expected payoff to the terrorists from initiating a hostage incident would be greater than the payoff of the status quo. Assuming the terrorists initiate a hostage event and achieve logistical success, the rational thing for the government to do in a one-shot game is to negotiate with the terrorists ( $\operatorname{set} p=1)$ and endure a loss of $-B$ rather than the greater loss of $-C$. The terrorists, using backward induction, can deduce that the rational play of the government is to set 
$p=1$. Hence, the terrorists can assume that the expected payoff from a hostage mission would in actuality be $Z=-\theta L+(1-\theta) M$, which is greater than the $Z$ value in equation (2) for all $p<1$.

The hostage game in Figure 6 is similar to an entry deterrence game, whereby a monopolist faces a threat of entry of another firm into its market. The monopolist can attempt to deter entry of the other firm by threatening to increase output and lower price should the rival enter. The problem for the monopolist is that, if the other firm enters, it is not in the monopolist's interest to lower its price after the fact. The potential entrant can thus dismiss the price-reducing threat of the incumbent as being not credible. The equilibrium outcome in the entry deterrence game is for the potential entrant to enter and for the monopolist to not lower price (Varian 2003, 509-510).

The government and terrorists in Figure 6 are analogous to the monopolist and potential entrant. One way for a government to deter a terrorist organization from initiating a hostage mission is to pre-commit to not negotiate with terrorists (setting $p=0$ in equation (2)). Since $N<M$, the non-negotiation commitment of the government, if believed by the terrorists, lowers the terrorists' expected payoff and potentially deters entry of the terrorists into a hostage mission. Just like the monopolist's threat to lower price in the entry deterrence game, the government's threat to not negotiate with terrorists calls for it to carry out an action that, after the fact, is not in its interest $(-C<-B){ }^{11}$

In the entry deterrence game, the challenge for the monopolist is to make credible its threat to lower price upon entry of a rival, when after the fact, it is not in the monopolist's interest to carry out the threat. One way the monopolist can increase the credibility of its threat is to invest in excess capacity (Varian 2003, 510). In international affairs, many governments adopt policies that pre-commit them to not negotiate with terrorists. In terms of the game tree of 
Figure 6, the pre-commitment policy, if believed by the terrorists, reduces the terrorists' expected payoff from a hostage mission. ${ }^{12}$

\section{Counterterrorism Games between Governments}

The hostage game above investigates strategic interdependence between a terrorist organization and a government. Here we consider the strategic interdependence between governments themselves as they attempt to thwart terrorism. Government efforts to thwart terrorism can be broadly classified as offensive or defensive. Offensive counterterrorism encompasses attacks against terrorist training centers, bases, resources, and leaders; terrorist group infiltration; and diminution of a terrorist group's ability to recruit members. Defensive counterterrorism involves placement of screening devices and barriers in airports and buildings; risk-reducing protocols for diplomats, businesspeople, military personnel, and tourists; and security alerts for private citizens and civil authorities. Although counterterrorism approaches cannot always be neatly classified as offensive or defensive, the distinction is useful because of various incentive issues faced by nations as they attempt to counter terrorism.

Consider, for example, offensive efforts to degrade al Qaeda. The security benefits of a diminished al Qaeda network are nonrival (can be enjoyed by other nations at zero added cost) and nonexcludable (can be enjoyed by other nations regardless whether they contribute to the efforts). Hence, degradation of al Qaeda is a public good for at-risk nations. According to public goods theory, these nations have an incentive to free ride on one another's efforts, which can lead to under-provision of offensive counterterrorism worldwide.

This quite naturally suggests modeling governments' offensive counterterrorism efforts as a prisoners' dilemma game (see, e.g., Lee 1988, Sandler 2003). Assume in the attempt to degrade an international terrorist organization, nations $A$ and $B$ simultaneously choose between 
two levels of offensive effort High and Low. To introduce explicit payoffs, suppose that strategy pair $\left(\operatorname{Low}_{A}, \operatorname{Low}_{B}\right)$ returns 0 to each nation. Suppose further that when either nation increases its effort to High, a resource cost of 6 is incurred by that nation alone, while an added security benefit of 5 is enjoyed by both nations.

The result is the prisoners' dilemma payoff matrix shown in Figure 7(a). To understand the payoffs, suppose $B$ chooses $H i g h$. If $A$ also chooses $H i g h$, then $A$ enjoys a security benefit of $5+5=10$ but incurs a resource cost of 6 , for a payoff of 4; alternatively, if $A$ free rides and chooses Low, then $A$ receives a benefit of 5 but incurs no cost, for a higher payoff of 5 . Suppose instead that $B$ chooses Low. If $A$ chooses High, then $A$ receives a benefit of 5 but a cost of 6 , for a payoff of -1; if $A$ chooses Low, then $A$ receives 0 benefit and incurs 0 cost, for a higher payoff of 0 . Hence, $A$ 's dominant strategy is to exercise a Low effort. The game is symmetric and results in the unique but Pareto inefficient Nash equilibrium $\left(\operatorname{Low}_{A}, \operatorname{Low}_{B}\right)$.

\section{Figure 7 here}

The prisoners' dilemma provides an intuitive explanation for the low levels of offensive counterterrorism effort prior to 9/11 (Cauley and Sandler 1988). However, the also familiar assurance and chicken games might prove to be more useful characterizations of offensive counterterrorism since 9/11. To illustrate the assurance game, again assume that a nation incurs a resource cost of 6 if it raises its effort to High. Now assume there exist what can be thought of as increasing returns to offensive counterterrorism efforts. If one nation increases its effort to High, an added security benefit of 2 is enjoyed by both nations, while if a second nation does the same, a further added benefit of 8 is generated.

The result is the assurance game of Figure 7(b), wherein a High effort is optimal only if matched by the other nation. Suppose $B$ chooses High. If $A$ also chooses High, then $A$ has a 
benefit of $2+8=10$ and incurs a cost of 6 , for a payoff of 4 ; if $A$ chooses Low, then $A$ has a benefit of 2 and no cost, for a lower payoff of 2. Suppose instead that $B$ chooses Low. If $A$ chooses $H i g h$, then $A$ receives a benefit of 2 and a cost of 6 , for a payoff of -4 ; if $A$ chooses Low, then $A$ has 0 benefit and cost, for a higher payoff of 0 . Note now that $A$ 's best reply depends on the strategy chosen by $B$, who faces symmetric incentives. Here there are two pure-strategy Nash equilibriums $\left(\operatorname{High}_{A}, \mathrm{High}_{B}\right)$ and $\left(\operatorname{Low}_{A}, \operatorname{Low}_{B}\right)$, where the former is Pareto superior to the latter. If free riding is the essence of the prisoners' dilemma, think of "I'll try only if you help" as the intuition of the assurance game. Sandler and Enders (2004, 310-311) suggest that the assurance game characterizes the coalition forged by the United States and Great Britain after 9/11.

There is, however, the suspicion that if the United States had found itself to be a coalition of one, it would nonetheless have increased its offensive counterterrorism efforts. Thus, consider the chicken game. Continue to assume that a nation incurs a resource cost of 6 if it chooses High, but assume now there exist what might be thought of as diminishing returns to offensive efforts. If one nation increases its effort to High, an added security benefit of 8 accrues to both nations, while if a second nation does the same, a further added benefit of 2 results.

The result is the chicken game of Figure 7(c), wherein a High effort is optimal when the other nation chooses Low. Leaving the confirmation of payoffs to the reader, note that the nations again have no dominant strategy. As in the assurance game, two pure-strategy Nash equilibriums arise, in this case $\left(\operatorname{Low}_{A}, \mathrm{High}_{B}\right)$ and $\left(\mathrm{High}_{A}, \operatorname{Low}_{B}\right)$, which are both Pareto efficient. Nation $A$ prefers the first equilibrium, wherein $B$ contributes the preponderance of effort and $A$ free rides, while $B$ prefers the second. The essence of this game is that each nation believes "something serious must be done" against the terrorists, but each prefers that the other take the lead. 
The prisoners' dilemma, assurance, and chicken games as presented here are distinguished by the size and behavior of security benefits relative to resource costs. Clearly, other games are both possible and plausible. For example, if security benefits are sufficiently high, then both nations can have a dominant strategy to commit a High effort. Or, to move away from symmetric games, if the security benefits vary between nations, one nation can have a dominant strategy of High while the other has a dominant strategy of Low. ${ }^{13}$

Whereas in the games above offensive counterterrorism effort by one nation can create a positive security externality for other nations, defensive effort against terrorists by one nation can create a negative security externality. For example, greater defensive barriers in the United States could cause terrorists to strike at less protected countries, as implied by the substitution principle. If nations' ignore the negative security externalities of terrorism defense, the result can be a Pareto inefficient allocation of terrorism defense worldwide. A variety of defensive counterterrorism games are possible depending on how security externalities and resource costs are structured in the game. ${ }^{14}$

\section{CONCLUSION}

For applications in an intermediate microeconomics course, one can perhaps draw from no richer or timelier area than terrorism. Virtually all features of the utility maximization model (e.g., Engel and price-consumption curves, substitution possibilities, Slutsky equation, etc.) can be used to explore terrorists' resource allocation and targeting behavior and governments' counterterrorism efforts. Game theory models are also helpful in understanding the strategic interdependence between a terrorist organization and a government and between governments themselves as they attempt to thwart terrorism. The natural interest students have in the terrorism problem can be leveraged to enhance students' learning of microeconomics theory. 
Moreover, students can better understand terrorism given the insights provided by microeconomic theory.

The microeconomics of terrorism also raises a number of broader methodological issues that students find interesting. For example, asking students whether terrorists are "rational" usually leads to animated discussion, which can eventually be directed to various ways that economists and non-economists characterize rational behavior. Hoffman $(1998,157)$ states that, "Contrary to both popular belief and media depiction, most terrorism is neither crazed nor capricious. Rather, terrorist attacks are generally both premeditated and carefully planned." Even though we might question the rationality of terrorist objectives, their methods of reaching objectives are rational in the common use of the term (i.e., premeditated and carefully planned). From an economic perspective, one can argue that terrorists are rational if, given their objectives, they respond to changes in their constraints in predictable ways (Sandler 1991, 13).

Another methodological issue that can be explored with students is the applicability of economic methods beyond the traditional boundaries of the discipline. According to Boulding (1971, 255), "Economics is significant, ...not merely because it investigates an important slice of life in the market place, but because the [choice] phenomena which emerge in a relatively clear and quantitative form in the market place are also found in virtually all other human activities." Boulding's statement does not mean there are no shortcomings associated with economic methodology, but that virtually all forms of human activity are amenable to economic analysis. When students see microeconomic theory applied to terrorism, they can better appreciate Boulding's point and arrive at a richer understanding of the role of microeconomic theory in exploring human behavior. 


\section{APPENDIX}

Table A here 


\section{NOTES}

1. Another well-known source of terrorist data is ITERATE (International Terrorism: Attributes of Terrorist Events), which uses information from print media to construct a database of international terrorism incidents from 1968-2003 (Mickolus et al., 2004). ITERATE data are also available from Vinyard Software, Inc. (ph: 703-560-3939). The U.S. State Department also publishes data on international terrorist attacks in the statistical appendix of its annual Global Terrorism Report (www.state.gov/s/ct/rls/pgtrpt/).

2. A simple linear regression of incidents on time yields a slope coefficient of $0.87(t=0.80)$ and R-square of 0.02 .

3. A simple linear regression of casualties on time yields a slope coefficient of $76.2(t=3.58)$ and R-square of 0.27. For casualties per incident, the corresponding figures are $0.36(t=3.26)$ and 0.24 .

4. On the composite good convention, see Nicholson $(2005,167-170)$.

5. The statement was attributed to bin Laden by President Clinton in a speech delivered on August 20, 1998 (http://usembassy-australia.state.gov/hyper/WF980828/epf502.htm).

6. In a more advanced utility maximization model, $R_{T}$ would be endogenous. For example, a utility function over $C$ and $T$ could be posited with $T$ in turn being a function of target choices (inputs) $T_{1}$ and $T_{2}$. The terrorist organization would allocate resources, $I$, over $C, T_{1}$, and $T_{2}$ to maximize utility.

7. Although the corner solution of the rational choice model might be considered idiosyncratic in most areas of economics, it may be useful in exploring suicide attacks (Sandler 2003, 784-785). 8. The results described above follow from the budget constraint and the expenditures test for elasticity. In the case in Figure 5, when $P_{C}$ is decreased, terrorists spend less on terrorism, since 
$P_{T}$ is unchanged and $T$ has decreased as dictated by a negatively-sloped price-consumption curve. With fixed income, nominal expenditures on the composite good must therefore increase when $P_{C}$ decreases. Because price and nominal expenditures move in opposite directions, $C$ is price elastic. Hence, a negatively-sloped price-consumption curve and decreased terrorism implies elastic demand. Reversing the argument, elastic demand implies a negatively-sloped price-consumption curve and decreased terrorism. Similar logic applies to the alternative case with a positively-sloped price consumption curve, increased terrorism, and inelastic demand. For further discussion, see Anderton and Carter (2004).

9. Greater defense of airlines and political figures by Israel in the early 1970s may have contributed to the seizure of eleven Israeli athletes by Palestinian terrorists at the 1972 Olympic Games in Munich. Fuad al-Shamali, one of the architects of the Munich hostage incident, described his substitution possibilities as follows: "We have to kill their most important and most famous people. Since we cannot come close to their statesmen, we have to kill artists and sportsmen" (Hoffman 1998, 71). In a similar vein, Enders and Sandler $(2000,380)$ warned that terrorist substitution possibilities could hurt the United States: "If a government responds by tightening security at official sites...as is currently being done in the United States, its civilian targets...will become relatively less secure...."

10. Scholars from a variety of disciplines have delved into why terrorists exist and how they are motivated (i.e., how terrorist preferences are formed). See, for example, Hoffman (1998) (Political Science), Hudson (1999) (Sociology and Psychology), Lewis (2003) (History), and Stout (2002) (Psychology).

11. Given that $-C<-B$, it should not be surprising to see governments occasionally reneging on pre-commitments not to negotiate with terrorists. For example, in November 1986, news media 
reported that the Reagan Administration deviated from its non-negotiation pledge when it traded arms to obtain the freedom of three American hostages (Lapan and Sandler 1988, 16). More recently, the Philippines apparently reversed course in its non-negotiation stance toward terrorists with the July 2004 pullout of Filipino troops from Iraq in exchange for a Filipino hostage. This action seemingly contradicted President Gloria Macapagal-Arroyo's statement in her commencement address at the University of Mindanao on April 22, 2003: "There will be no letdown in our operations against the Abu Sayyaf and other terrorist groups as may be identified with firmness. And we will not negotiate with terrorists who are doing terrorists acts" (www.op.gov.ph/speeches.asp?iid=324\&iyear=2003\&imonth=4).

12. For an extension of the hostage game in Figure 6 to a multi-period setting with reputation effects see Lapan and Sandler (1988).

13. Another well-known game is battle-of-the sexes, whereby each player is better off when they pick the same action relative to the case where they choose different actions. The game has two pure-strategy Nash equilibriums, but the preferences of the players over the equilibriums are in conflict. Battle-of-the-sexes could be applied when, for example, one nation prefers a preemptive war strategy while another nation prefers sanctions and diplomacy. 14. On various game theory models and issues associated with defensive counterterrorism games between governments, see Sandler (2003, 787-789) and Sandler and Siqueira (2003). 


\section{REFERENCES}

Anderton, C.H. and J.R. Carter. 2004. On rational choice theory and the study of terrorism. Mimeo.

Boulding, K.E. 1971. Is economics necessary? In Kenneth E. Boulding: Collected papers, volume II, ed. F.R. Glahe. Boulder, CO: Colorado Associated University Press. (Originally published in 1949 in Scientific Monthly 68 (April): 235-240.)

Cauley, J. and T. Sandler. 1988. Fighting world war III: A suggested strategy. Terrorism: An International Journal 11 (Fall): 181-195.

Cavanaugh, W.T. 2004. Sins of omission: What "religion and violence" arguments ignore. The Hedgehog Review 6 (Spring): 34-50.

Enders, W. and T. Sandler. 1993. The effectiveness of anti-terrorism policies: Vectorautoregression-intervention analysis. American Political Science Review 87 (November): 829-844.

Enders, W. and T. Sandler. 1995. Terrorism: Theory and applications. In Handbook of defense economics, ed. K. Hartley and T. Sandler. Amsterdam: Elsevier.

Enders, W. and T. Sandler. 2000. Is transnational terrorism becoming more threatening? A times series investigation. Journal of Conflict Resolution 44 (June): 307-332.

Frey, B.S. and S. Luechinger. 2003. How to fight terrorism: Alternatives to deterrence. Defence and Peace Economics 14 (August): 237-249.

Hoffman, B. 1998. Inside terrorism. New York: Columbia University Press.

Hudson, R.A. 1999. The sociology and psychology of terrorism: Who becomes a terrorist and why? Washington, DC: Library of Congress, Federal Research Division.

Juergensmeyer, M. 2000. Terror in the mind of God: The global rise of religious violence. Berkeley, CA: University of California Press.

Krueger, A.B. and Malečková, J. 2003. Education, poverty and terrorism: Is there a causal connection? Journal of Economic Perspectives 17 (Fall): 119-144.

Lapan, H. and T. Sandler. 1988. To bargain or not to bargain?: That is the question. American Economic Review 78 (May): 16-21.

Lewis, B. 2003. The crisis of Islam: Holy war and unholy terror. New York: Modern Library.

Lee, D.R. 1988. Free riding and paid riding in the fight against terrorism. American Economic Review 78 (May): 22-26. 
Mickolus, E.F., T. Sandler, J.M. Murdock, and P. Flemming. 2004. International terrorism: Attributes of terrorist events, 1968-2003 (ITERATES). Dunn Loring, VA: Vinyard Software, Inc.

Nicholson, W. 2005. Microeconomic theory. $9^{\text {th }}$ ed. Mason, OH: Southwestern.

Sandler, T. 1991. Economic analysis can help fight international terrorism. Challenge 34 (January-February): 10-17.

Sandler, T. 2003. Collective action and transnational terrorism. The World Economy 26 (June): 779-802.

Sandler, T. and W. Enders. 2004. An economic perspective on transnational terrorism. European Journal of Political Economy 20 (June): 301-316.

Sandler, T. and K. Hartley. 1995. The economics of defense. New York: Cambridge University Press.

Sandler, T. and K. Siqueira. 2003. Global terrorism: Deterrence versus preemption. Mimeo.

Stout, C. ed. 2002. The psychology of terrorism, 4 volumes. Westport, CT: Greenwood Press.

Varian, H. 2003. Intermediate microeconomics: A modern approach. $6^{\text {th }}$ ed. New York: W.W. Norton \& Co. 


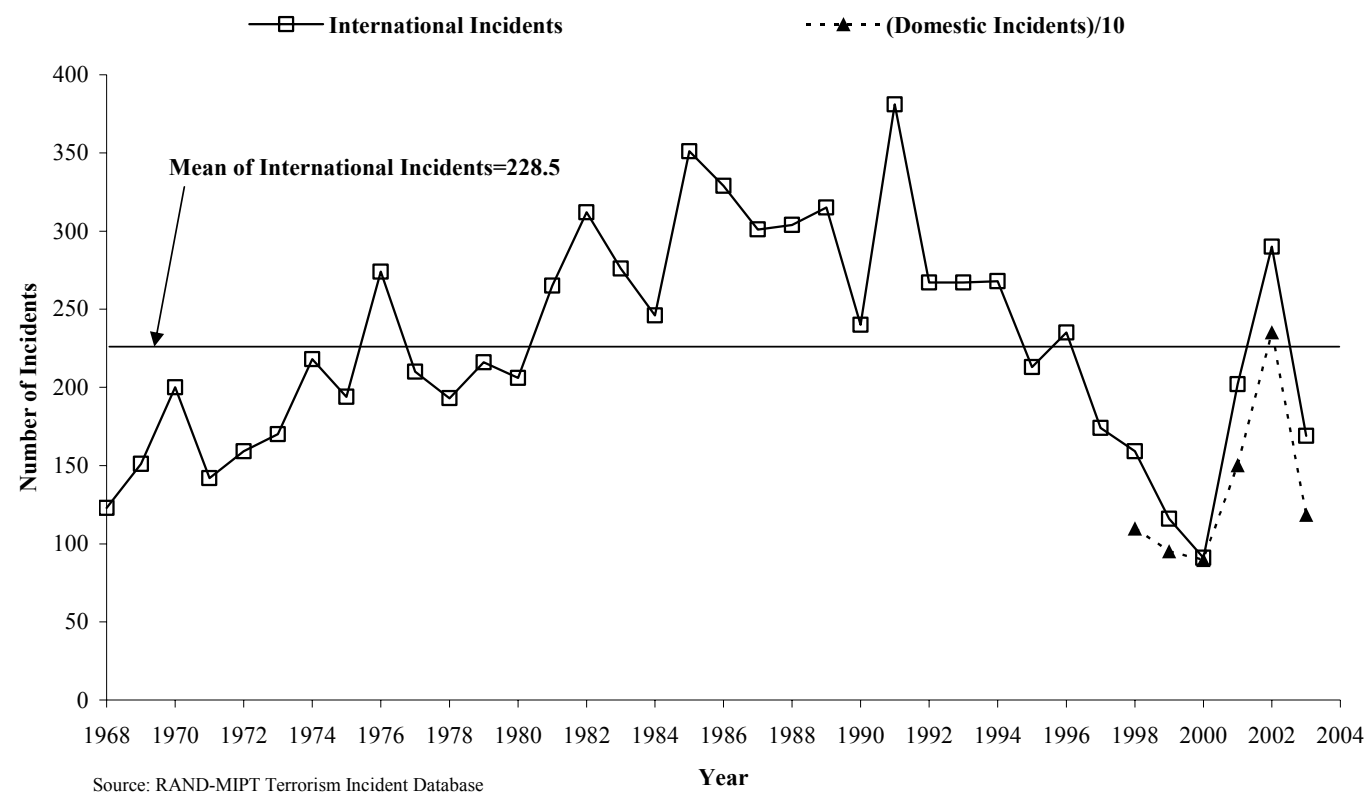

Figure 1. Worldwide Terrorist Incidents

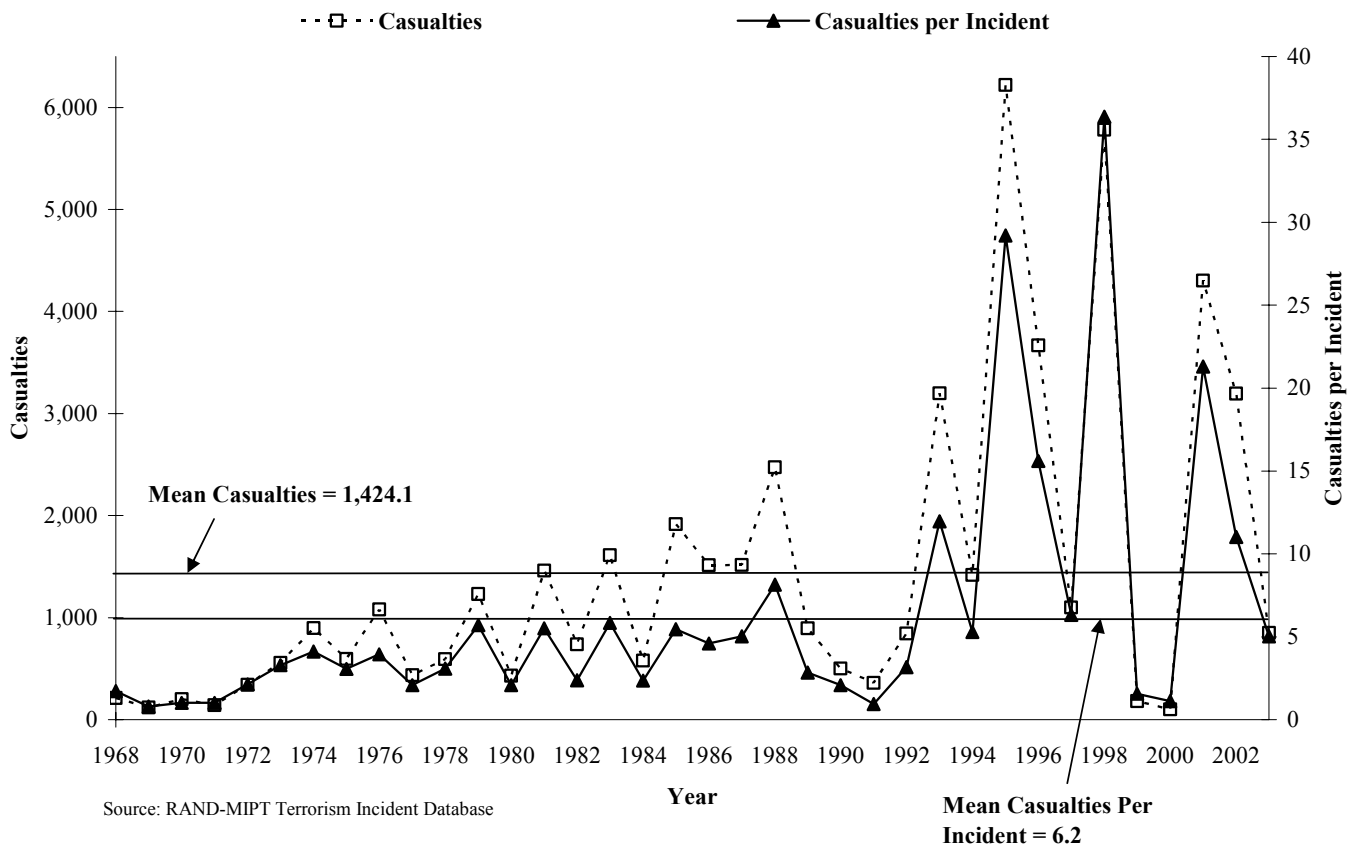

Figure 2. Worldwide Casualties (Deaths+Injured) from International Terrorist Incidents 


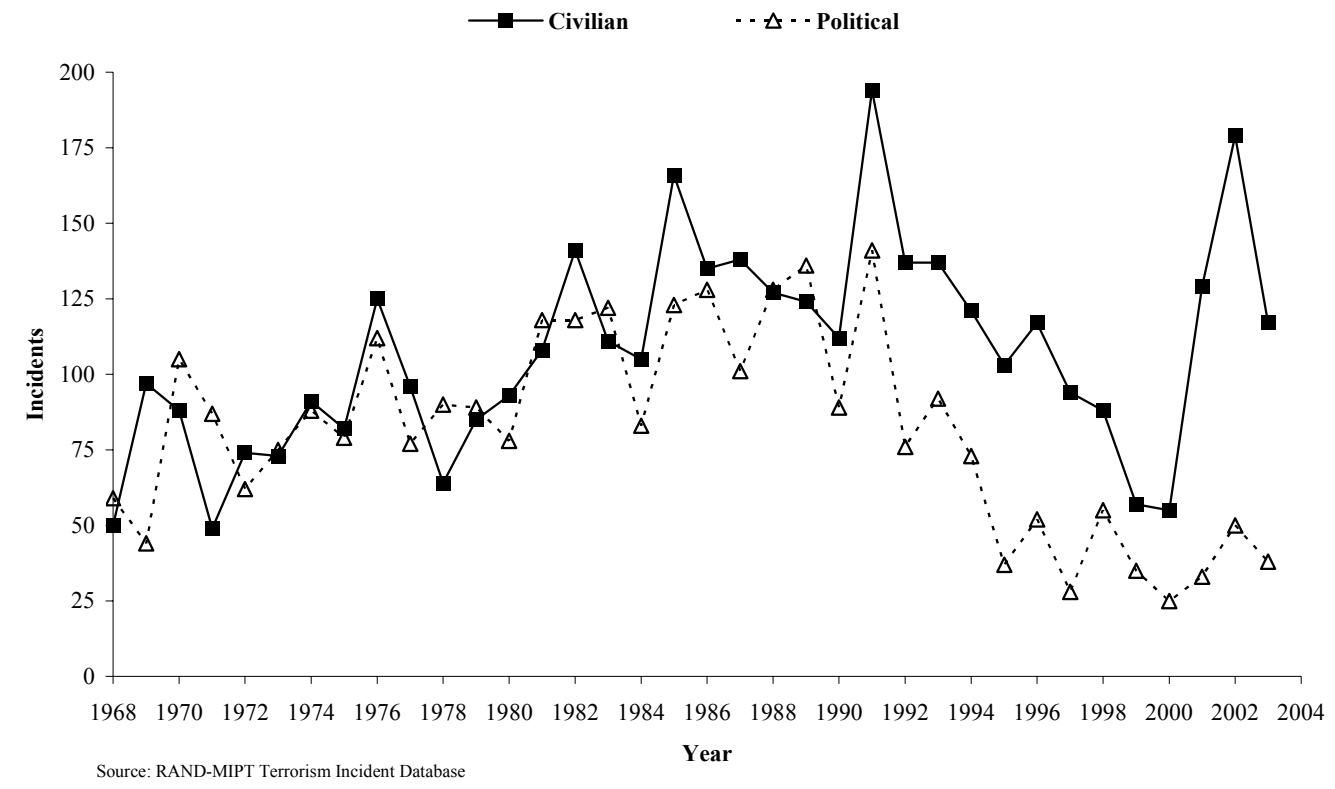

Figure 3. International Terrorist Incidents by Target

(a)

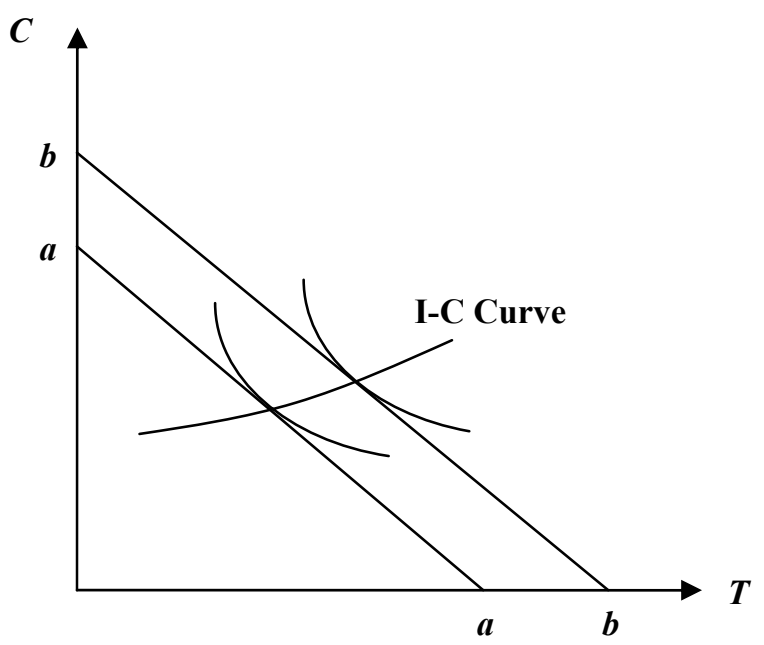

(b)

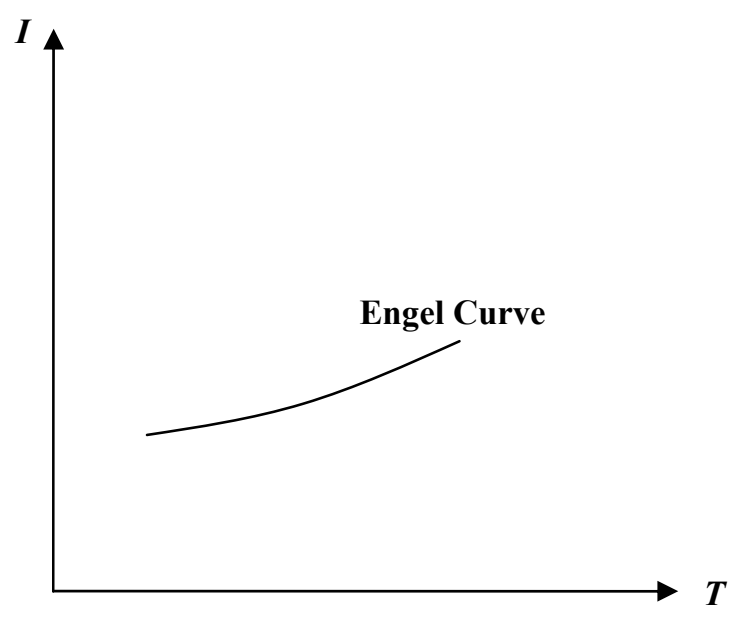

Figure 4. Income-Consumption (I-C) Curve and Engel Curve for Terrorism 


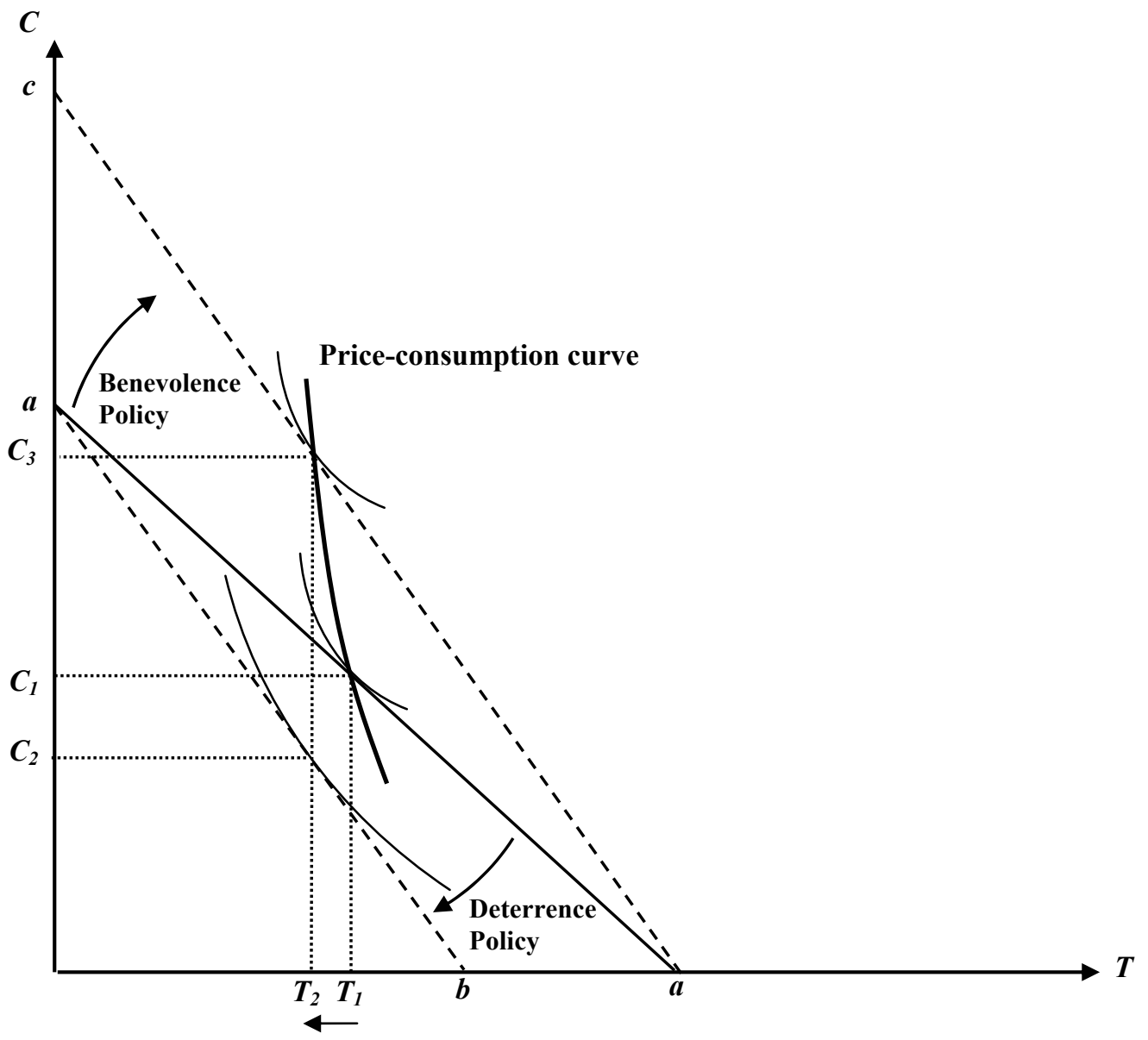

Figure 5. Deterrence and Benevolence Price Policies to Reduce Terrorism

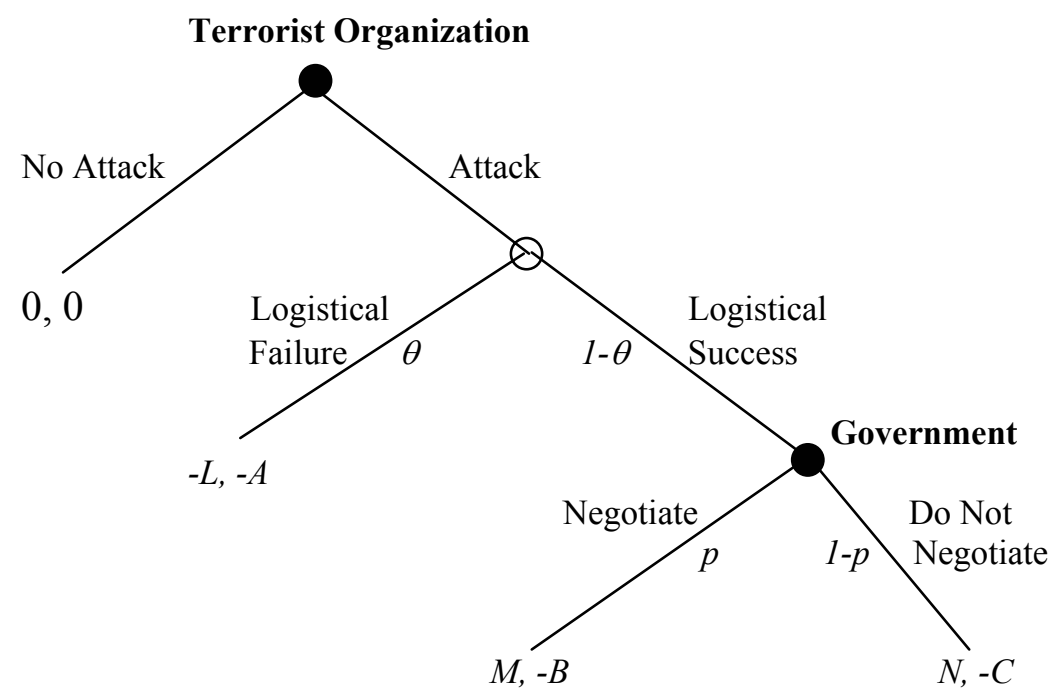

Source: Lapan and Sandler (1988)

Figure 6. Government-Terrorist Hostage Game 
(a) Prisoners' Dilemma

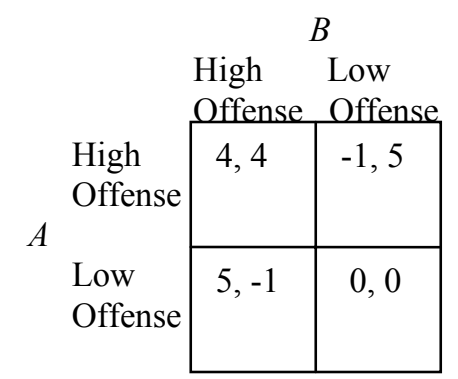

\section{(b) Assurance}

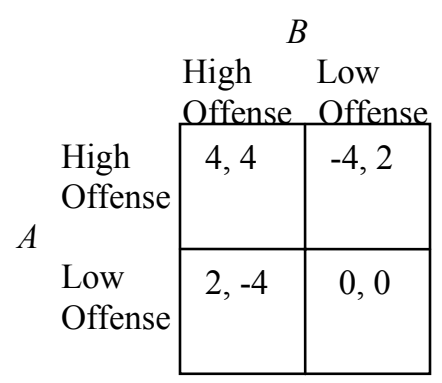

(c) Chicken

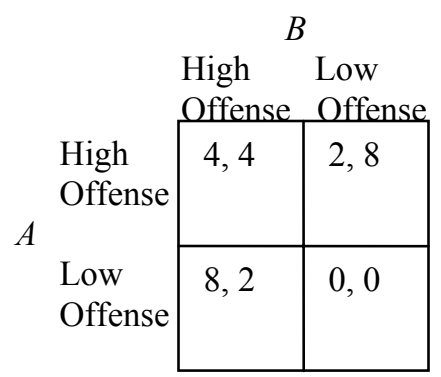

Figure 7. Offensive Counterterrorism Games between Governments

Table 1. International Terrorist Hijackings, 1968-1980

\begin{tabular}{|l|ccc|}
\hline Year & \multicolumn{2}{|l}{ Total International } & Hijackings as \\
Incidents & Hijackings & $\begin{array}{l}\text { Percent of Total } \\
\text { Per }\end{array}$ \\
1969 & 123 & 26 & 21.1 \\
1970 & 151 & 72 & 47.7 \\
1971 & 200 & 50 & 25.0 \\
1972 & 142 & 16 & 11.3 \\
$\mathbf{1 9 7 3}^{*}$ & 159 & 26 & 16.4 \\
1974 & $\mathbf{1 7 0}$ & $\mathbf{1 1}$ & $\mathbf{6 . 5}$ \\
1975 & 218 & 7 & 3.2 \\
1976 & 194 & 3 & 1.5 \\
1977 & 274 & 8 & 2.9 \\
1978 & 210 & 20 & 9.5 \\
1979 & 193 & 9 & 4.7 \\
1980 & 216 & 12 & 5.6 \\
\hline Mean & 206 & 22 & 10.7 \\
\hline
\end{tabular}

* Metal Detectors Placed in Airports, 1973

Source: RAND/MIPT 
Table A. Terrorism Incidents, Casualties, and Targets, 1968-2003

\begin{tabular}{|c|c|c|c|c|c|c|c|}
\hline \multirow[b]{2}{*}{ Year } & \multirow{2}{*}{$\begin{array}{r}\begin{array}{c}\text { Domestic } \\
\text { Terrorism }\end{array} \\
\\
\text { Incidents }\end{array}$} & \multicolumn{6}{|c|}{$\begin{array}{c}\text { International } \\
\text { Terrorism }\end{array}$} \\
\hline & & Incidents & Casualties & $\begin{array}{l}\text { Casualties } \\
\text { per Incident }\end{array}$ & $\begin{array}{l}\text { Civilian } \\
\text { Targets }^{\mathrm{a}}\end{array}$ & $\begin{array}{l}\text { Political } \\
\text { Targets }^{\mathrm{a}}\end{array}$ & $\begin{array}{r}\text { Ratio of } \\
\text { Civilian to } \\
\text { Political } \\
\text { Targets }\end{array}$ \\
\hline 1968 & & 123 & 212 & 1.7 & 50 & 59 & 0.85 \\
\hline 1969 & & 151 & 120 & 0.8 & 97 & 44 & 2.20 \\
\hline 1970 & & 200 & 202 & 1.0 & 88 & 105 & 0.84 \\
\hline 1971 & & 142 & 144 & 1.0 & 49 & 87 & 0.56 \\
\hline 1972 & & 159 & 340 & 2.1 & 74 & 62 & 1.19 \\
\hline 1973 & & 170 & 558 & 3.3 & 73 & 75 & 0.97 \\
\hline 1974 & & 218 & 897 & 4.1 & 91 & 88 & 1.03 \\
\hline 1975 & & 194 & 595 & 3.1 & 82 & 79 & 1.04 \\
\hline 1976 & & 274 & 1,080 & 3.9 & 125 & 112 & 1.12 \\
\hline 1977 & & 210 & 436 & 2.1 & 96 & 77 & 1.25 \\
\hline 1978 & & 193 & 594 & 3.1 & 64 & 90 & 0.71 \\
\hline 1979 & & 216 & 1,231 & 5.7 & 85 & 89 & 0.96 \\
\hline 1980 & & 206 & 430 & 2.1 & 93 & 78 & 1.19 \\
\hline 1981 & & 265 & 1,460 & 5.5 & 108 & 118 & 0.92 \\
\hline 1982 & & 312 & 739 & 2.4 & 141 & 118 & 1.19 \\
\hline 1983 & & 276 & 1,613 & 5.8 & 111 & 122 & 0.91 \\
\hline 1984 & & 246 & 580 & 2.4 & 105 & 83 & 1.27 \\
\hline 1985 & & 351 & 1,918 & 5.5 & 166 & 123 & 1.35 \\
\hline 1986 & & 329 & 1,514 & 4.6 & 135 & 128 & 1.05 \\
\hline 1987 & & 301 & 1,516 & 5.0 & 138 & 101 & 1.37 \\
\hline 1988 & & 304 & 2,474 & 8.1 & 127 & 128 & 0.99 \\
\hline 1989 & & 315 & 894 & 2.8 & 124 & 136 & 0.91 \\
\hline 1990 & & 240 & 500 & 2.1 & 112 & 89 & 1.26 \\
\hline 1991 & & 381 & 362 & 1.0 & 194 & 141 & 1.38 \\
\hline 1992 & & 267 & 844 & 3.2 & 137 & 76 & 1.80 \\
\hline 1993 & & 267 & 3,197 & 12.0 & 137 & 92 & 1.49 \\
\hline 1994 & & 268 & 1,418 & 5.3 & 121 & 73 & 1.66 \\
\hline 1995 & & 213 & 6,219 & 29.2 & 103 & 37 & 2.78 \\
\hline 1996 & & 235 & 3,667 & 15.6 & 117 & 52 & 2.25 \\
\hline 1997 & & 174 & 1,100 & 6.3 & 94 & 28 & 3.36 \\
\hline 1998 & 1,097 & 159 & 5,781 & 36.4 & 88 & 55 & 1.60 \\
\hline 1999 & 951 & 116 & 182 & 1.6 & 57 & 35 & 1.63 \\
\hline 2000 & 897 & 91 & 102 & 1.1 & 55 & 25 & 2.20 \\
\hline 2001 & 1,503 & 202 & 4,304 & 21.3 & 129 & 33 & 3.91 \\
\hline 2002 & 2,352 & 290 & 3,196 & 11.0 & 179 & 50 & 3.58 \\
\hline 2003 & 1,186 & 169 & 850 & 5.0 & 117 & 38 & 3.08 \\
\hline Mean & $1,331.0$ & 228.5 & $1,421.1$ & 6.3 & 107.3 & 81.3 & 1.55 \\
\hline
\end{tabular}

${ }^{a}$ Civilian and political incidents sum to less than total incidents because the targets for some incidents are not specified or are categorized as "maritime" or "police." Since some nations integrate their maritime and police forces into the military and others do not, we excluded terrorist attacks against maritime or police targets from the civilian/political tabulations.

Source: RAND/MIPT 